
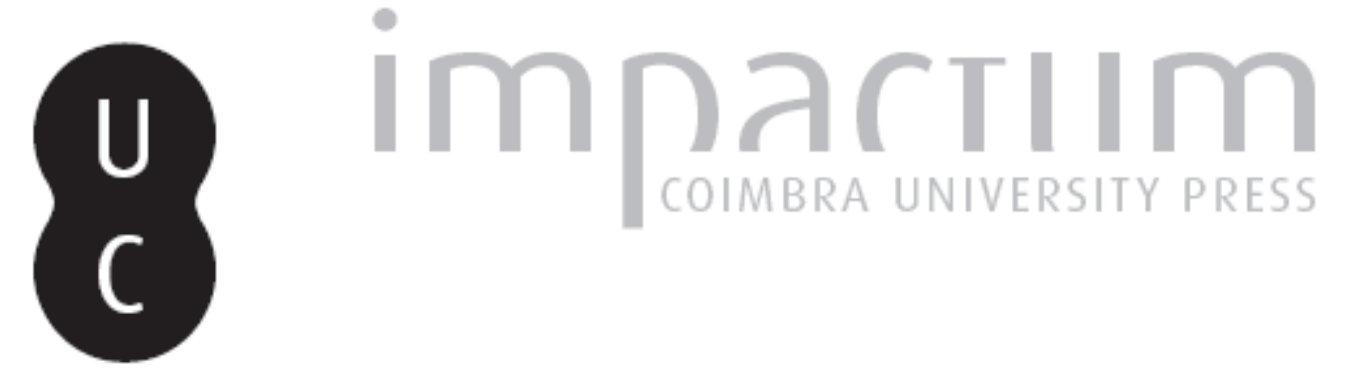

Comunicação política em terras de jurisdição senhorial: os casos de Faro e de Vila Viçosa (1641-1715)

Autor(es): $\quad$ Cunha, Mafalda Soares da; Farrica, Fátima

Publicado por: Faculdade de Letras da Universidade de Coimbra, Instituto de História

URL

persistente: Económica e Social

DOI: $\quad$ DOI:http://dx.doi.org/10.14195/0870-4147_44_12

Accessed : $\quad$ 26-Apr-2023 11:52:49

A navegação consulta e descarregamento dos títulos inseridos nas Bibliotecas Digitais UC Digitalis, UC Pombalina e UC Impactum, pressupõem a aceitação plena e sem reservas dos Termos e Condições de Uso destas Bibliotecas Digitais, disponíveis em https://digitalis.uc.pt/pt-pt/termos.

Conforme exposto nos referidos Termos e Condições de Uso, o descarregamento de títulos de acesso restrito requer uma licença válida de autorização devendo o utilizador aceder ao(s) documento(s) a partir de um endereço de IP da instituição detentora da supramencionada licença.

Ao utilizador é apenas permitido o descarregamento para uso pessoal, pelo que o emprego do(s) título(s) descarregado(s) para outro fim, designadamente comercial, carece de autorização do respetivo autor ou editor da obra.

Na medida em que todas as obras da UC Digitalis se encontram protegidas pelo Código do Direito de Autor e Direitos Conexos e demais legislação aplicável, toda a cópia, parcial ou total, deste documento, nos casos em que é legalmente admitida, deverá conter ou fazer-se acompanhar por este aviso.

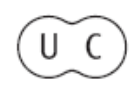




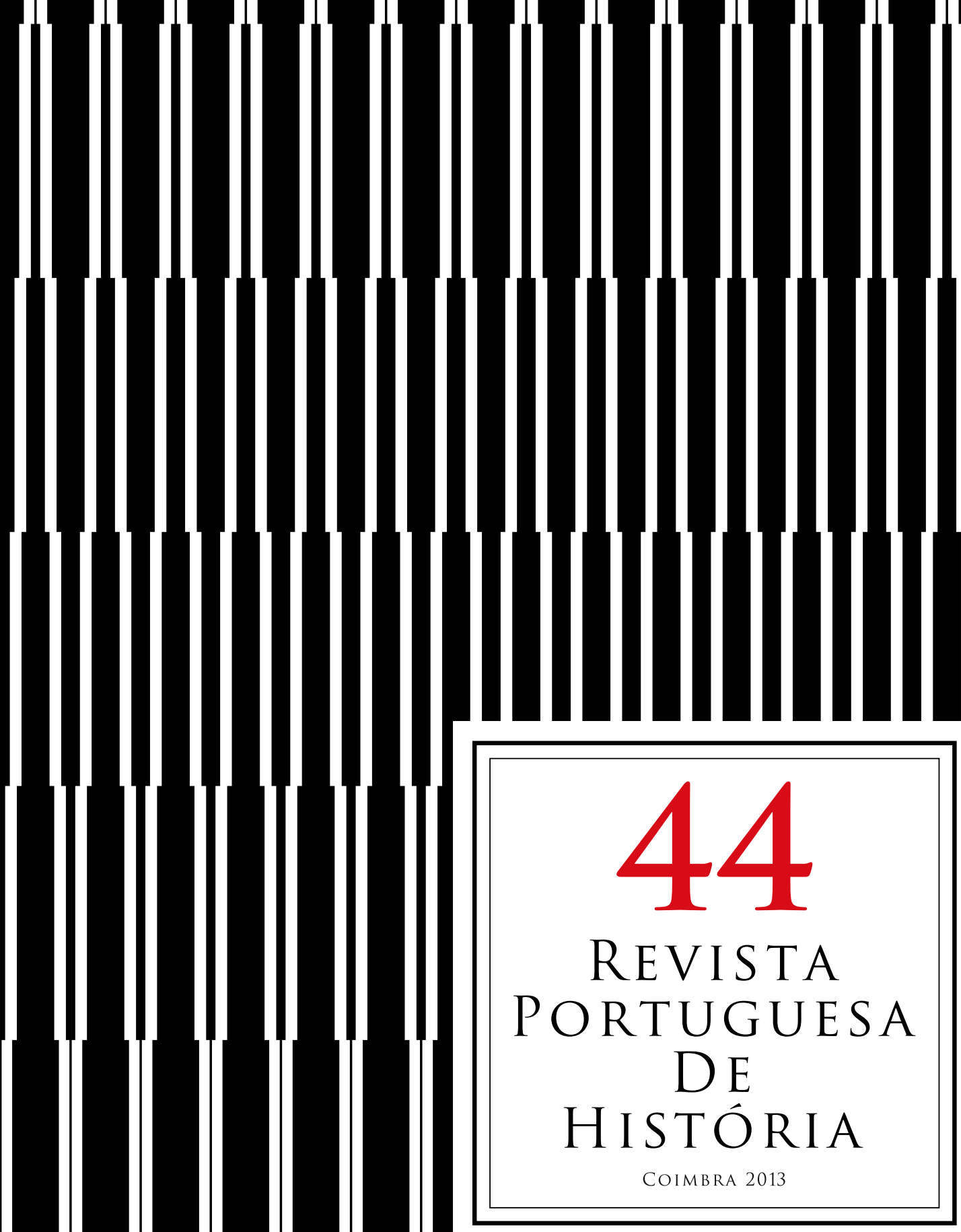




\title{
Comunicação política em terras de jurisdição senhorial. Os casos de Faro e de Vila Viçosa (1641-1715)
}

\author{
Mafalda Soares da Cunha \\ CIDEHUS-UÉ \\ mafaldascunha@gmail.com \\ FÁtima FARRICA \\ CIDEHUS-UÉ \\ fatimafarrica@sapo.pt
}

Resumo:

No âmbito do projecto A comunicação política na monarquia pluricontinental portuguesa (1580-1808): Reino, Atlântico e Brasil (PTDC/HIS-HIS/098928/2008) é nosso propósito analisar os temas, os fluxos e os agentes da comunicação estabelecida entre instâncias políticas sob jurisdição senhorial. O objectivo central do texto visa aprofundar a compreensão do funcionamento do sistema político da época moderna, assente num matizado de jurisdições, através dos processos de disseminação de decisões e de legislação, das suas formas de imposição e de resolução de conflitos.

A partir de uma abordagem inédita de fontes documentais, principalmente dos livros de registo de cartas, provisões e alvarás - das câmaras Vila Viçosa e de Faro - empreende-se uma análise comparativa da comunicação destas câmaras de jurisdição senhorial, respectivamente, da Casa de Bragança e da Casa das Rainhas, dando-se especial relevância às questões de índole militar nos períodos das Guerras da Restauração e da Guerra de Sucessão de Espanha.

Palavras chave:

Comunicação Política; Casa de Bragança; Casa da Rainha; Poder senhorial.
Abstract:

Within the scope of the project Political communication in multi-continental Portuguese monarchy (1580-1808): the kingdom, the Atlantic, and Brazil (PTDCHIS-HIS0989 282008), it is our purpose to analyse the topics, the flows, and the agents of the communication between political bodies under manorial jurisdiction. The central objective of the article is to deepen the understanding of how the political system, based on a melange of jurisdictions, worked in the Early Modern Era. This will be done examining the processes of dissemination of decisions and laws, their enforcement and the ways of conflict resolution.

An original approach of documentary sources, mainly record books of letters, provisions and charts - issued by the municipalities of Vila Viçosa and Faro - allows for a comparative analysis of the communication between such municipalities which were under the jurisdiction, respectively, of the House of Bragança and of the house of the Queens, with particular relevance to military matters during the War of Restoration and the War of Spanish Succession.

Keywords:

Communication; Political system; Early Modern Era; Municipalities; War. 


\section{Introdução $^{1}$}

O ponto de partida deste texto nasce da classificação feita há muito por A.M. Hespanha nas suas Vésperas do Leviathan ${ }^{2}$ em que o autor sugere que o dia-a-dia da Monarquia se teria organizado em torno da coexistência de três poderes: o poder da Coroa, o poder dos municípios e o do poder senhorial. Estas três dimensões do poder objectivam-se através de uma arquitectura política com geometrias e geografias variadas e mutáveis. Que implicam e exigem comunicação entre essas várias dimensões do poder e ainda com os vassalos do rei. Como se caracteriza, se estrutura e evolui essa comunicação no quadro amplo da monarquia pluricontinental portuguesa é um dos objectivos centrais de um projecto luso-brasileiro que está na sua fase final ${ }^{3}$. Procurando ultrapassar debates nem sempre bem fundados empiricamente, decidiu esta equipa de investigação promover a análise destas questões a partir de levantamentos sistemáticos de informação em distintos fundos de arquivo relacionados com as estruturas de governo e de comunicação destas três dimensões de poder num âmbito cronológica e geograficamente alargado.

Se é este o contexto académico em que este artigo se inscreve, os seus objectivos são bastante mais modestos. Desde logo porque constitui um primeiro ensaio de tratamento serial dos dados recolhidos que muito beneficiará do diálogo com os resultados de outros trabalhos do projecto ainda em curso. Mas também do ponto de vista temático já que se limita à análise da comunicação política em terras de jurisdição senhorial com base na comparação entre dois municípios - Faro e Vila Viçosa - pertencentes à Casa da Rainha e à Casa de Bragança. Está bem estabelecido pela historiografia que estas duas instituições senhoriais, pelo facto de serem casas da família real, apresentam particularismos face às restantes. Mantêm no entanto uma estrutura de governo e uma relação

1 As autoras agradecem os comentários a este texto feitos pelos colegas do projecto: Nuno G. Monteiro, Pedro Cardim, José Damião Rodrigues e Ronald Raminelli.

2 António Manuel Hespanha, As Vésperas do Leviathan: Instituições e Poder Político: Portugal-séc. XVII, Lisboa, 1986.

3 A comunicação política na monarquia pluricontinental portuguesa (1580-1808): Reino, Atlântico e Brasil (PTDC/HIS-HIS/098928/2008), dirigido por Nuno Gonçalo Monteiro e financiado pela Fundação para a Ciência e Tecnologia e que conta com uma equipa de investigadores multi-institucionais (Instituto de Ciências Sociais da Universidade de Lisboa, Centro Interdisciplinar de História, Culturas e Sociedades da Universidade de Évora, Centro de História de Além-Mar da Faculdade de Ciências Sociais e Humanas da Universidade Nova de Lisboa e da Universidade dos Açores, Universidade Federal do Rio de Janeiro, Universidade Federal Fluminense, Universidade Rural do Rio de Janeiro, Universidade de Juiz de Fora e ainda Universidade de Viçosa). 
com as suas terras de tipo senhorial, além de a própria especificidade da sua natureza constituir um interessante ponto de observação sobre as características e a própria configuração desse poder. Que diferenças apresentam face aos poderes senhoriais tradicionais, ou seja, face às casas senhoriais da nobreza não pertencente à família real? Que tipo de relação estabelecem com os seus territórios? Como se articulam com os demais poderes em presença? Como reagem aos desafios políticos nascidos da subida ao poder da dinastia de Bragança?

A resposta a esta última questão teve consequências determinantes na delimitação cronológica da análise. Considerou-se assim que o estudo da comunicação dos donatários com as suas terras poderia beneficiar muito do confronto e da comparação entre diferentes contextos políticos. Sabendo-se que a guerra constitui um poderoso factor de promoção de novidades e mudanças institucionais com inevitáveis reajustes nos equilíbrios políticos e sociais decidiu-se abarcar o período pós-Restauração até ao final da Guerra de Sucessão de Espanha. O objectivo mais concreto é o de avaliar o impacto das guerras da Restauração e da Sucessão de Espanha, em que o reino esteve envolvido, na comunicação política dos senhorios com os seus municípios ao mesmo tempo que se compara a intervenção senhorial na gestão do território com a dos organismos da coroa em circunstâncias que se podem classificar como ordinárias e em contextos de pressão defensiva. A expectativa de partida é a de que as situações de conflito aberto gerarão uma maior intensidade de comunicação por parte da coroa, mas não será de somenos relevância observar o comportamento dos senhorios nesse processo e assim também avaliar a propalada diluição da sua esfera de acção no campo militar.

\section{Faro e Vila Viçosa, terras de senhorio}

Faro, cidade do reino do Algarve desde 1540 e sede de bispado a partir de 1577, foi reintegrada na Casa da Rainha após a entronização da dinastia de Bragança. Em 1700 o seu município tinha uma extensão de $388 \mathrm{~km}^{2}$ e contava com uma população de 11.391 habitantes ${ }^{4}$. Tornou-se sede de ouvidoria a partir de $1669^{5}$, com tutela sobre três concelhos contíguos - Silves, Alvor e Faro ${ }^{6}-$

\footnotetext{
4 António Manuel Hespanha, As Vésperas do Leviathan....

5 Arquivo Distrital de Faro (ADF), Câmara de Faro, Sr. A/1, Livro 01, fl. 172.

6 Maria Paula Marçal Lourenço, Casa, Corte e Património das Rainhas de Portugal (1640-1754): Poderes, Instituições e Relações Sociais, Lisboa, Universidade de Lisboa, 1999, (Tese de Doutoramento policopiada), vol. 2, p. 827.
} 
constituindo-se como a maior ouvidoria da Casa da Rainha em área, embora fosse a que continha menos população. Já Vila Viçosa era cabeça do ducado de Bragança desde o terceiro quartel do século XV. A sua circunscrição era relativamente pequena, pois não ia além dos $163 \mathrm{~km}^{2}$, mas em 1700 albergava 4.620 habitantes $^{7}$. Foi também sede de uma das quatro ouvidorias dessa casa senhorial. Em território era a segunda maior ouvidoria do ducado de Bragança, bastante mais extensa do que a de Faro, mas tal como esta uma das menos povoadas. Já a densidade demográfica tem valores bastante semelhantes, embora ao nível municipal seja significativamente superior ao do quadro comarcão: 29 hab $/ \mathrm{km}^{2}$ para o caso de Faro e $28 \mathrm{hab} / \mathrm{km}^{2}$ para o de Vila Viçosa. Com efeito, as comarcas apresentavam uma baixa densidade demográfica que rondava os $14 \mathrm{hab} / \mathrm{km}^{2}$ para o caso alentejano contra $12 \mathrm{hab} / \mathrm{km}^{2}$ para o algarvio. Os termos dos núcleos urbanos seriam assim pouco populosos. Aspecto relevante é que, ao contrário de Faro, a ouvidoria de Vila Viçosa era geograficamente dispersa e englobava doze localidades algumas das quais distantes da cabeça da ouvidoria: Monforte, Alter do Chão, Margem e Logomel, Sousel, Monsaraz, Portel, Arraiolos, Borba, Vila Boim, Evoramonte, Chancelaria e Vila Viçosa.

De acordo com Romero Magalhães, a cidade de Faro teria conhecido um crescimento muito moderado ao longo do século XVII, entrecortado por duros revezes. A peste de 1649-50 deixou-lhe marcas. Em 1672 apontam-se-lhe 1018 fogos, que rondariam as 4072 almas $^{8}$. Em 1687 um pouco menos ${ }^{9}$. Já antes o saque dos ingleses, em 1596, destruíra parte da cidade e do seu termo ${ }^{10}$. De qualquer modo, Faro seria uma cidade opulenta com rendimentos significativos para a fazenda real por conta das almadravas de atum, renda das sardinhas, sal e pescado e alfândega ${ }^{11}$. Teria, inclusivamente, adquirido preeminência no conjunto do Algarve desde o século XVI, ultrapassando as demais cidades desse reino. Quanto ao todo algarvio, após uma depressão ao longo de 1591 a 1631, entrou em estagnação até 1672, voltando a adquirir algum dinamismo entre 1672 e $1758^{12}$.

7 António Manuel Hespanha, As Vésperas do Leviathan...

8 Joaquim Romero Magalhães, O Algarve Económico. 1600-1773, Lisboa, Editorial Estampa, 1988 , p. 61.

9 Joaquim Romero Magalhães, O Algarve Económico..., p. 106.

${ }^{10}$ Joaquim Romero Magalhães, $O$ Algarve Económico..., p. 19.

${ }^{11}$ Joaquim Romero Magalhães, O Algarve Económico..., p. 105.

${ }^{12}$ Joaquim Romero Magalhães, O Algarve Económico..., p. 20. 
Segundo os dados disponíveis, Vila Viçosa revela um comportamento demográfico declinante desde o século $\mathrm{XVI}^{13}$ que se prolonga até 1651 . De então, e pelo menos até 1667, parece ter recuperado população. A guerra terá, quanto muito, travado um crescimento mais expressivo ${ }^{14}$. São tendências que surpreendem e que ficam a pedir esclarecimentos adicionais pois esperar-se-ia que a fixação da sede da corte ducal em Vila Viçosa, desde os inícios do século XVI, tivesse gerado um impacto demográfico positivo nesse território, fazendo também sentido que a sua saída para Lisboa após 1640 provocasse uma contracção populacional.

Como é bem conhecido pela historiografia, o estatuto quer da Casa de Bragança, quer da Casa da Rainha sofreu alterações com a subida ao trono de D. João IV. No que respeita a esta última, foi restaurada por carta patente de D. João IV, em $1642^{15}$, após ter sido extinta durante o domínio filipino, período em que os seus bens foram incorporados na Coroa e depois doados a vários membros da nobreza ${ }^{16}$. Seguiram-se confirmações régias das doações e dos privilégios da Casa, datadas de 1643, 1644 e 1645 que lhe reconstituíram as bases territoriais e os privilégios detidos durante a dinastia dos Avis, além de fixarem o seu quadro orgânico ${ }^{17}$. As titulares da Casa podiam ser a rainha consorte, a rainha viúva ou a rainha reinante, o que ocorreu pela primeira vez com D. Maria I. Perante a inexistência daquelas figuras a administração da Casa seria assegurada pelo próprio monarca. Estava sedeada no Palácio Real, coexistindo com a corte régia ${ }^{18}$.

Já no que toca à Casa de Bragança, a ascensão do duque D. João II a rei de Portugal implicou a transferência imediata da corte ducal e da sede do governo do ducado para Lisboa. Levantou-se depois a questão de como definir e considerar juridicamente a posse dos territórios e o governo do senhorio. De acordo com uma proposta apresentada nas cortes de 1641 decidiu-se

${ }^{13}$ Jorge Fonseca, “A população do arcebispado de Évora em 1592”, Callipole. Revista de Cultura, n. ${ }^{\text {s }} 10-11,2002-2003$, p. 33-47.

${ }^{14}$ Joaquim Romero Magalhães, $O$ Algarve Económico..., p. 25.

${ }^{15}$ Maria Paula Marçal Lourenço, Casa, Corte e Património..., vol. 2, p. 751.

${ }^{16}$ Maria Paula Marçal Lourenço, Casa, Corte e Património..., vol. 2, p. 751-752 e José Subtil, "O Estado e a Casa da Rainha: entre a véspera do terramoto e o Pombalismo", Politeia: História e Sociedade, vol. 8, n 1, 2008, p. 146.

${ }^{17}$ A Doação das Terras, Jurisdições e Direitos da Rainha Dona Luísa - E Regimento do seu Ouvidor, por D. João IV, data de 10 de Janeiro de 1643. Vid. José Justino de Andrade e Silva (comp.e anot.), Collecção Chronologica da Legislação Portugueza - 1640-1647, Lisboa, Imprensa de J. J. A. Silva, 1854, p. 176. E ainda Maria Paula Marçal Lourenço, Casa, Corte e Património..., vol. 2, p. 751 e 822 e José Subtil, “O Estado e a Casa da Rainha...”, p. 147.

${ }^{18}$ José Subtil, "O Estado e a Casa da Rainha...”, p. 131-132. 
conservar a Casa de Bragança como estrutura senhorial autónoma dos bens da Casa Real. A questão demorou a concretizar-se, pois só por carta patente de 27 de Outubro de $1645^{19}$ é que se regulamentou a sua administração e formas sucessórias, para além de se justificar a decisão pela necessidade de dotar os sucessores do trono com uma casa própria. A Casa de Bragança passou, assim, a ser a casa do herdeiro da coroa. Por isso, os primogénitos para além do título de príncipes do Brasil passaram a usar o de duques de Bragança. O sucessor da Casa seria o príncipe herdeiro, assim que nascesse, mas a sua administração só lhe seria entregue quando se lhe criassem casa e estado próprios, o mesmo é dizer quando atingisse a maioridade. Até lá seria administrada pelo soberano. Deste modo o titular do governo da casa só se diferenciaria do titular do governo da monarquia entre as datas da sua maioridade e da sua ascensão ao trono. Nessa ocasião a titulatura e o governo da Casa seriam de novo assegurados pelo monarca. E, com efeito, entre 1641 e 1715, por vicissitudes diversas, como a menoridade ou a incapacidade dos herdeiros da Coroa, a Casa de Bragança foi quase sempre administrada pelo próprio rei. A carta patente de 1645 estabelecia, igualmente, que a administração seria sempre separada da Casa Real e dos bens próprios da Coroa $^{20}$. Com estas determinações pretendia-se evitar que os bens da Casa viessem a ser integrados nos da Coroa, caso a dinastia de Bragança algum dia deixasse de reinar.

Em ambas as Casas as decisões últimas pertenciam aos respectivos titulares (rainha ou duque/rei), ainda que tomadas com base nas consultas feitas a tribunais superiores próprios de cada uma destas casas senhoriais: o Conselho da Fazenda e Estado da Rainha e a Junta da Justiça da Casa de Bragança.

O Conselho da Fazenda e Estado da Rainha, segundo Subtil, talvez existisse já em meados do século XVI ${ }^{21}$, embora Paula Lourenço tivesse fixado a data da sua criação apenas em 16 de Julho de $1643^{22}$. Em todo o caso, as competências desse tribunal só seriam fixadas em 1656, através do Regimento emitido por despacho da rainha D. Luísa de Gusmão²3. Quanto à Junta da Justiça da

${ }^{19}$ F.A. F. Silva Ferrão, Tractado sobre Direitos e Encargos da Sereníssima Casa de Bragança, Lisboa, Imprensa de J.J. Andrade e Silva, 1852, p. 115.

${ }^{20}$ Mafalda Soares da Cunha, "A Casa de Bragança (séculos XIV-XVIII): Permanência, plasticidade e participação política”, in D. João VI: um rei aclamado na América-Anais do Seminário Internacional, Rio de Janeiro, Museu Histórico Nacional, 2000, p. 283.

${ }^{21}$ José Subtil, "O Estado e a Casa da Rainha...", p. 134.

${ }^{22}$ Maria Paula Marçal Lourenço, Casa, Corte e Património..., vol. 1, p. 77 e vol. 2, p. 76.

${ }^{23}$ Roberto Monteiro de Campos Coelho e Sousa, Systema, ou Collecção dos Regimentos Reaes, Lisboa, Oficina de Francisco Borges de Sousa, Tomo V, 1789, p. 658; Maria Paula 
Casa de Bragança, a forma de decisão em "junta" já existia antes de $1640{ }^{24}$, apesar de as suas atribuições só terem sido fixadas em 1687, data do Regimento da Casa de Bragança ${ }^{25}$.

Órgãos de governo central destas casas, as juntas eram encabeçadas por desembargadores que, assessorados por pessoal variado, despachavam as matérias de jurisdição dos respectivos senhorios. Eram tribunais de recurso judicial de terceira instância, que tinham equivalência no Desembargo do Paço e no Conselho da Fazenda relativamente à administração da justiça, fazenda, graça, mercês e ofícios ${ }^{26}$.

Embora estas duas casas tivessem dimensões territoriais bastante diferentes, ambas tinham jurisdição completa, ou seja, cível e crime, mero e misto império, direito de nomeação de justiças, de dada de ofícios, dos padroados e das alcaidarias-mores ${ }^{27}$. $\mathrm{O}$ alargado leque de privilégios de que usufruíam incluía também a isenção da correição régia ${ }^{28}$. Porém, os ouvidores das rainhas, de acordo com o decreto de 3 de Novembro de $1644^{29}$, tinham ainda a prerrogativa de exercerem o cargo de provedores, atributo que não existia para os mesmos ministros das casas de Bragança ou do Infantado, em cujas terras entravam os provedores régios.

Em matéria de governo local, estas instituições senhoriais nomeavam as vereações eleitas nas suas terras. Em alguns casos a presidência das câmaras era assegurada por juízes de fora nomeados directamente pelos titulares das casas. De acordo com Paula Lourenço, a Casa da Rainha nomeava seis desses magistrados para nove lugares nos onze concelhos da $\mathrm{Casa}^{30}$. O que significa

Marçal Lourenço, Casa, Corte e Património..., vol. 2, p. 777 e José Subtil, "O Estado e a Casa da Rainha...", p. 148.

${ }^{24}$ Mafalda Soares da Cunha, A Casa de Bragança (1560-1640): práticas senhoriais e redes clientelares, Lisboa, Editorial Estampa, 2000, p. 274.

${ }^{25}$ Regimento da Serenissima Casa de Bragança, Lisboa, Officina de Miguel Manescal, 1690.

${ }^{26}$ Maria Paula Marçal Lourenço, Casa Corte e Património ..., vol. 2, p. 782-784; José Subtil, "O Estado e a Casa da Rainha...", p. 134 e Fátima Farrica, Poder sobre as periferias: a Casa de Bragança e o governo das terras no Alentejo (1640-1668), Lisboa, Colibri. CIDEHUS-UÉ, 2011, p. 47- 48 .

${ }^{27}$ Mafalda Soares da Cunha, A Casa de Bragança (1560-1640)..., p. 209-214 e 221 e Maria Paula Marçal Lourenço, Casa, Corte e Património..., vol. 2, p. 819-820.

${ }^{28}$ A Casa de Bragança tinha isenção de correição concedida em 1521. Mafalda Soares da Cunha, A Casa de Bragança (1560-1640)..., p. 221. A Casa das Rainha tinha isenção de correição dada por D. João III em 1550 e confirmada, depois, por D. João IV. Maria Paula Marçal Lourenço, Casa, Corte e Património..., vol. 2, p. 820.

${ }^{29}$ José Justino de Andrade e Silva (comp. e anot.), Collecção Chronologica da Legislação - 1640-1647..., p. 256.

${ }^{30}$ Maria Paula Marçal Lourenço, Casa Corte e Património..., vol. 2, p. 863 e 827. 
que certas vilas teriam governos conjuntos e seriam presididas pelo mesmo magistrado. No que respeita à Casa de Bragança, esta nomeava catorze juízes de fora para os quarenta e dois concelhos sob a sua jurisdição ${ }^{31}$. No período em análise, tanto em Faro como em Vila Viçosa a presidência da câmara era assegurada por um juiz de fora.

Com funções de tutela sobre os juízes de fora, sobre os processos de eleição das vereações municipais e com outras competências similares aos corregedores régios, encontravam-se os ouvidores senhoriais que superintendiam os territórios das ouvidorias. Eram igualmente nomeados por cada uma destas casas senhoriais e exerciam a justiça em segunda instância, com isenção de correição régia ${ }^{32}$. Respondiam directamente perante o Conselho da Fazenda e Estado da Rainha e perante a Junta da Justiça da Casa de Bragança.

Quer os ouvidores, quer os juízes de fora eram nomeados por períodos de três anos, mas os mandatos dessas magistraturas podiam ser prolongados sempre que se justificasse. As razões maioritariamente invocadas para a prorrogação dos prazos eram o bom desempenho de funções, a falta de substitutos para os cargos, ou até, a petição das próprias populações.

Como se compreende, o quadro orgânico e as competências de governo territorial destas duas casas decalcavam, no essencial, as estruturas régias da administração periférica e local. E tal como nos concelhos sob jurisdição da Coroa a comunicação entre o titular das terras e as câmaras podia ser feita directamente ou de forma intermediada. No primeiro caso quem assinava a correspondência era o rei ou rainha. No segundo as missivas podiam ser firmadas pelos tribunais superiores das casas (Conselho da Fazenda e Estado da Rainha ou a Junta da Justiça da Casa de Bragança) ou pelos magistrados senhoriais (ouvidores ou juízes de fora). Este conjunto de emissores será designado ao longo da análise como "emissores senhoriais" (Tabela 5) ou "instâncias senhoriais".

Importa todavia sublinhar que as três casas da Família Real com administração autónoma criadas (a Casa da Rainha, a Casa de Bragança e a Casa do Infantado) tinham algumas características distintas das demais casas senhoriais. A mais significativa prende-se com o facto de os titulares de cada uma delas serem membros da família real, coincidindo nos casos de Bragança e da Rainha, muitas vezes com o rei e a rainha. Mas outra das especificidades relaciona-se com o sistema de transmissão de bens instituído para ambas nos respectivos

${ }^{31}$ Fátima Farrica, Poder sobre as periferias..., p. 43-59.

${ }^{32}$ José Subtil, "O Estado e a Casa da Rainha...”, p. 146 e Fátima Farrica, Poder sobre as periferias..., p. 53 . 
Regimentos. Ao impedir a criação de uma linha sucessória independente da família real, evitou-se que estas casas se transformassem em típicas casas senhoriais. Como consequência, a Coroa manteve um controlo estreito sobre uma ampla extensão senhorial no reino que se diferenciava das terras régias pelo facto de manterem uma estrutura de organização e de funcionamento separada da Coroa e que detinha privilégios jurisdicionais extraordinários enraizados há muito nas práticas políticas dos seus vassalos. Recentemente tem-se até chamado a atenção para o maior peso e a maior eficácia das suas formas de enquadramento político e territorial face a outras casas senhoriais e face às terras da $\operatorname{Coroa}^{33}$.

A existência deste tipo particular de casas senhoriais gerou três consequências. Uma primeira foi a de constituir um verdadeiro entrave ao crescimento de casas senhoriais exteriores à família real, o que desequilibrou decisivamente as relações entre a coroa e a nobreza. Recorde-se a este propósito que a decisão de constituir três casas para a família real com base nos bens de algumas das mais importantes casas senhoriais (Bragança, Vila Real, Castelo Rodrigo, Alenquer) ${ }^{34}$ do período em que Portugal fez parte da Monarquia dos Áustrias implicou tornar esses mesmos bens indisponíveis para novas doações a membros da nobreza. Esta restrição ao volume de bens da Coroa passíveis de serem doados pode, em nosso entender, ajudar a explicar a reduzida dimensão das casas senhoriais da dinastia de Bragança, bem como o baixo nível de territorialização do seu poder senhorial e a elevada dependência da Coroa que Nuno G. Monteiro tão bem demonstrou há já alguns anos ${ }^{35}$. Note-se, por isso, que a maior casa senhorial da dinastia de Bragança foi a dos duques de Cadaval (antes marqueses de Ferreira), casa que até 1640 nunca lograra ser mais do que a quinta (ou mesmo a sexta) casa senhorial do reino.

Em segundo lugar deve mencionar-se que a criação destas Casas regulou o acesso dos descendentes da casa real a estados senhoriais, assim institucionalizando soluções que evitavam as complicações e os embaraços políticos que tinham ocorrido no interior da própria família real ao longo da dinastia de Avis.

Um terceiro efeito foi o de possibilitar que a Coroa assegurasse um controlo senhorial de forma muito estável sobre amplas extensões territoriais do reino.

${ }^{33}$ Fátima Farrica, Poder sobre as periferias..., p. 76-82.

${ }^{34}$ Maria Paula Marçal Lourenço, Casa, Corte e Património...,vol. 1, p. 77-78.

${ }^{35}$ Nuno Gonçalo Monteiro, O Crepúsculo dos Grandes: A casa e o património da aristocracia em Portugal (1750-1832), $2^{\text {a }}$ ed. revista, Lisboa, Imprensa Nacional-Casa da Moeda, 2003. 
Como é também já conhecido pela historiografia ${ }^{36}$, o facto de essas jurisdições incluírem privilégios e direitos que remontavam a épocas muito anteriores muitos dos quais fixados na longínqua centúria de quatrocentos - que, para mais, eram defendidas por instâncias judiciais próprias, facilitou a consolidação de formas de governação e de exacção de rendas mais pesadas com um mínimo de contestação das populações. Nesta óptica quer a Casa da Rainha quer a Casa de Bragança mantinham uma relação de tipo senhorial com as populações, embora os seus recursos revertessem para e servissem as estratégias da monarquia.

\section{Caracterização das fontes documentais}

O nosso corpus documental primário é constituído pelos livros de registo de alvarás, provisões e cartas depositados nos arquivos camarários das duas localidades $^{37}$. Estes integram apenas a documentação recebida pela câmara ${ }^{38} \mathrm{e}$, tanto quanto se conheça, não há qualquer outra série documental nos arquivos municipais que colija a documentação por ela expedida. A única forma de aceder a dados sobre a emissão de correspondência da câmara é a detecção nas cartas recebidas de fórmulas de resposta. Estas características da documentação representam uma importante limitação aos propósitos do estudo da comunicação política com os municípios que importa desde já reter.

Os livros de registo de alvarás, provisões e cartas existem em todos os municípios. Na sua origem estaria uma disposição régia para a preservação da documentação relativa às terras que data pelo menos de finais do século XV. Com efeito, nas cortes de Lisboa de 1498 estipulou-se que os oficiais da câmara deviam mandar fazer um cofre-forte e bom, de três fechaduras, para guardar as eleições dos oficiais. Cada uma das chaves ficaria em posse

${ }^{36}$ Ana Maria S. A. Rodrigues, "Poderes Concorrentes e seus Agentes na Torres Vedras Quatrocentista," Amar, Sentir e Viver a História. Estudos de Homenagem a Joaquim Veríssimo Serrão, Lisboa, 1995, p. 49-73; Manuela Santos Silva, "Óbidos 'Terra que foi da Rainha D. Filipa'. (O senhorio de Óbidos de 1415 a 1428)," A Região de Óbidos na Época Medieval: Estudos, Caldas da Rainha, 1994, p. 86-109; Manuela Santos Silva, "Notícia sobre a segunda doação régia de Alenquer, Óbidos e Sintra à Rainha D. Leonor de Lencastre (Évora, 15 de Abril de 1491)," A Região de Óbidos na Época Medieval: Estudos, Caldas da Rainha, 1994, p. 110-119.

${ }^{37}$ ADF, Câmara de Faro, Sr. A/1, Livro 01 e 02. Arquivo Histórico Municipal de Vila Viçosa (AHMVV), Câmara de Vila Viçosa, RG 703 e 722. As autoras agradecem à Câmara Municipal de Vila Viçosa e ao Arquivo Distrital de Faro as autorizações concedidas para a consulta e a reprodução da documentação que constitui as fontes de informação fundamentais para este estudo.

${ }^{38}$ Salvo em casos muito pontuais em que também aí se registaram cartas emitidas pelos municípios. 
de cada um dos vereadores do ano anterior, assim garantindo que nenhuma pessoa singular possuísse mais do que uma chave. Deviam, igualmente, dispor de uma arca grande e boa para guardar privilégios, tombos, forais, escrituras e coisas que pertencessem à cidade ou à vila. Uma das chaves da arca seria detida pelo escrivão da câmara e a outra por um vereador do ano em curso $^{39}$. Estas determinações foram, posteriormente, incluídas nas Ordenações Manuelinas e nas Ordenações Filipinas no título referente ao escrivão da câmara ${ }^{40}$. O texto repete-se em ambos os códigos, estipulando que o escrivão da câmara deveria ter uma das chaves da arca do concelho onde se guardavam os forais, tombos, privilégios e outras escrituras referentes à localidade.

A guarda, a preservação e a não adulteração dos documentos que registavam os direitos e os privilégios de cada um dos municípios era um assunto da máxima importância. Constituíam um corpus de originais que podia ser extenso e que certamente incluía documentos bastante antigos. Acredita-se que inicialmente os documentos fossem guardados como peças avulsas nas tais arcas. No entanto, o passar dos tempos deteriorara ou permitira o extravio de muitos deles pelo hábito que havia de deixar sair os papéis do cartório. Tais situações obrigaram os oficiais camarários a tomar providências para a salvaguarda dos respectivos arquivos. Essas diligências assumiram a forma de petições para as tutelas para que estas permitissem a cópia desses originais para um livro, com a garantia de que os traslados assim compilados deveriam ter o mesmo crédito e fiabilidade que os originais. Conhecem-se as autorizações concedidas aos pedidos efectuados pelas câmaras de Coimbra em $1608^{41}$, de Faro em $1645^{42}$ e de Évora em 1693 e $1696^{43}$. Os livros resultantes dessas iniciativas podiam assim incluir documentação com datas bastante variadas e não incluem certamente o total do acervo da documentação recebida e/ou produzida por cada município,

${ }^{39}$ Cortes de Lisboa de 1498. Capítulo XLIX. Como hão-de estar em guarda nas Câmaras, os privilégios e Eleições dos Oficiais, in, $2^{\circ}$ Visconde de Santarém, Memórias e Alguns Documentos para a História e Teoria das Côrtes Geraes que em Portugal se Celebraram pelos Três Estados do Reino. Parte II. Documentos, Lisboa, Impressão Régia, 1828, p. 292-293.

${ }^{40}$ Ordenações Manuelinas, nota de apresent. Mário Almeida Costa, Lisboa, Fundação Calouste Gulbenkian, 1984, Livro 1, Título LII. "Do Escrivão da Câmara e coisas que a seu Ofício pertencem"; Ordenações Filipinas, nota de apresent. Mário Almeida Costa Lisboa, Fundação Calouste Gulbenkian, 1985, Livro 1, Título LXXI. "Do Escrivão da Câmara".

${ }^{41}$ José Justino de Andrade e Silva (comp. e anot.), Collecção Chronologica da Legislação Portugueza-1603-1612..., p. 223-224.

42 ADF, Câmara de Faro, Sr. A/1, Lv. 01, fl. 013.

${ }^{43}$ José Justino de Andrade e Silva (comp. e anot.), Collecção Chronologica da Legislação Portugueza-1683-1700..., p. 327 e p. 393. 
mas apenas aquela que nesses momentos estaria disponível e era considerada importante para atestar o conjunto de direitos e privilégios das câmaras.

No entanto, a par destes livros, destinados a recuperar a informação em risco, gerou-se a prática mais corrente de o escrivão da câmara ir registando (ou seja copiando) em livro a correspondência recebida de interesse para o município. Assim, surgiram os livros de registo de alvarás, provisões e cartas. Estes documentos deviam ser copiados com regularidade e, para evitar perdas de informação, com proximidade cronológica à sua recepção pela câmara. Os termos de abertura desses livros atestam-no. Em Vila Viçosa existem dois livros para o período em estudo. Um respeita os anos entre 1579 e 1650, o outro refere-se ao intervalo entre 1653 e 1750 e abre dizendo "Livro que serve dos registos do senado da câmara desta vila"44. Para Faro existem igualmente dois livros, com documentação relativa aos anos de 1596-1710 e 1710-1744 ${ }^{45}$. No termo de encerramento do segundo deles explicava-se: “(...) este livro que há-de servir para se lançarem por registo as provisões e mais coisas pertencentes à câmara desta cidade (...)" ${ }^{\prime 46}$. Resulta, portanto, claro que se fixaram procedimentos quotidianos de registo e que a triagem do que devia ou não ser copiado dependia de critérios que seriam fixados pelas vereações.

A análise da documentação contida nestes livros de registo clarifica que não se copiaram só documentos oriundos das instituições centrais da Coroa ou das Casas, mas também outros documentos com emissores, receptores e conteúdos muito diversificados. Este conjunto documental tinha uma tipologia variada - alvarás, provisões, cartas, mas também certidões, licenças, sentenças, cartas de privilégio, cartas de ofício, etc. As certidões, licenças, sentenças, cartas de privilégio, cartas de ofício diziam quase sempre respeito a assuntos particulares. Nestes casos, os registos eram efectuados por solicitação de um particular ou de uma instituição (as já referidas cartas de privilégios ou cartas de ofícios mecânicos, por exemplo) e as datas da sua cópia no livro de registo camarário podiam distanciar-se bastante da data de emissão do documento, sendo registados apenas no momento em que era necessário invocar um privilégio ou certificar uma qualquer autorização. Mas não só. Dilações no registo poderiam acontecer também noutras tipologias documentais, como sucedeu com o alvará que difundia o regimento do Real de Água que, embora

\footnotetext{
${ }^{44}$ AHMVV, Câmara de Vila Viçosa, RG 722 e RG 704.

${ }^{45}$ ADF, Câmara de Faro, Sr. A/1, Lv. 01 e 02.

${ }^{46}$ ADF, Câmara de Faro, Sr. A/1, Lv. 03.
} 
tivesse sido emitido pelo monarca em 23 de Janeiro de 1643, só foi registado em Vila Viçosa em $1717^{47}$.

Excluindo estas situações, os critérios de selecção da documentação para registo permanecem pouco claros. Parece evidente que havia prioridade de registo relativamente às cartas emanadas do centro político. De qualquer forma, o confronto da totalidade das cartas disponíveis nos vários arquivos municipais revela que mesmo assim haveria falhas de registo. A situação mais ilustrativa verifica-se na câmara de Évora. Uma vez que o cartório deste município detém códices separados com as compilações das cartas originais recebidas, podemos constatar que a informação que hoje aparece nos livros de registo dessa câmara constitui apenas uma parte da documentação que para lá foi enviada. O mesmo se pode afirmar para Vila Viçosa, já que se encontraram 108 cartas originais anexadas aos seus livros de vereação, cuja cópia não existe nos livros de registo. De resto e de acordo com os dados do projecto em curso A comunicação política na monarquia pluricontinental portuguesa antes mencionado, este problema de perda de informação será extensível à maior parte das câmaras do império.

De igual modo se desconhece se os critérios eram seguidos de forma igual em todas as câmaras. Cremos que não. Acreditamos assim que o volume de documentação registada resultaria de uma casuística dependente dos decisores e dos intervenientes no processo, ou seja dos vereadores e talvez até do próprio escrivão da câmara. Talvez dependesse também da atitude de outros participantes nesse processo, como os juízes de fora, os ouvidores e os provedores. É que algumas das cartas registadas eram dirigidas a estes magistrados e eram eles quem se deslocava às câmaras da sua jurisdição para que o conteúdo desses documentos se copiasse nos livros de registo. Tal verificava-se porque importava disseminar a informação aí contida para o concelho e lugares do termo e registá-la para consulta e uso futuro. Essa a razão pela qual em alguns registos de cartas em Vila Viçosa nos anos posteriores a 1668 se anotou no fim do registo as datas em que as mesmas tinham sido lidas e divulgadas nas freguesias do termo. Ou como aconteceu em Faro, onde alguns registos contêm certidão a informar a data em que a carta fora publicada na praça e ruas públicas da vila de Loulé. Outras nas de Tavira. Mas este cuidado seria casuístico e circunstancial. Pela análise de conteúdo percebe-se que estas cautelas eram maiores quando se tratava de divulgação de leis. Em qualquer caso, as cartas originais eram devolvidas a quem as apresentava depois de copiadas. Não há certeza, no entanto, que todos os oficiais envolvidos cumprissem com rigor a obrigação

\footnotetext{
${ }^{47}$ AHMVV, Câmara de Vila Viçosa, RG 722, fl. 449v.
} 
de informação. O desleixo, a ausência do serviço e a pressa podem ser factores plausíveis para omissões de registo por alguns escrivães da câmara.

É claro que a dimensão demográfica e a relevância económica e política das terras também poderiam constituir indicadores comparativos sobre o volume de documentação recebida que se esperaria encontrar. Mas o facto de Vila Viçosa apresentar números de documentação registada superiores a Faro leva-nos a duvidar da aplicabilidade deste critério, pelo menos no que respeita ao fluxo de comunicação. Com efeito, embora Faro tivesse uma área e uma dimensão demográfica superiores encontramos apenas 512 cartas registadas, enquanto Vila Viçosa apresenta 709. Uma primeira justificação para esta disparidade prende-se com o facto de para Vila Viçosa se terem incorporado nestas contagens as 108 cartas originais que o município anexou aos seus livros de vereação, o que não foi feito em Faro. E, como se verá dentro em pouco, estas 108 cartas também inflacionam o peso da comunicação das instâncias senhoriais brigantinas, já que o titular da Casa de Bragança é o seu principal emissor.

Em conclusão, os registos que aqui se analisarão não revelam todo o universo documental de comunicação da época com as câmaras de Faro e de Vila Viçosa e impõem cautelas à sua análise comparada. São advertências que importa ter presentes, pois introduzem limites evidentes ao estudo que aqui se efectuará. Em qualquer dos casos, e uma vez que este tipo de séries documentais constitui a mais completa fonte de informação de que dispomos sobre esta matéria, consideramos que o seu estudo apresenta inegáveis virtualidades analíticas e interpretativas sobre a comunicação política entre centros e territórios no século XVII.

\section{Emissores e assuntos}

Na maioria dos casos, os emissores da correspondência registada em ambas as câmaras eram instituições (centrais, periféricas ou locais). Este tipo de emissores é por nós designado "emissores institucionais" e contrapõe-se aos emissores individuais. Os primeiros incluem o monarca, os donatários, os tribunais centrais da Coroa e dos senhorios, os oficiais periféricos régios e senhoriais, bem como outras instâncias de governo: secretarias, juntas, vedorias, etc. Entre 1600 e 1700 verificam-se 502 ocorrências de emissores institucionais registados em Faro e 705 em Vila Viçosa. O segundo tipo de emissores tem uma expressão reduzida em ambos os municípios - dez indivíduos em Faro e quatro sujeitos em Vila Viçosa - pelo que não serão incluídos nesta análise. 
Tabela 1 - Emissores institucionais principais (1641-1715)

\begin{tabular}{|c|r|r|r|r|}
\hline Assuntos & \multicolumn{2}{|c|}{ Faro } & \multicolumn{2}{c|}{ Vila Viçosa } \\
\hline Total cartas - governo militar & 150 & $29,8 \%$ & 69 & $9,8 \%$ \\
\hline Total cartas - instâncias senhoriais & 116 & $23,1 \%$ & 252 & $35,7 \%$ \\
\hline Total cartas - monarca & 87 & $17,3 \%$ & 259 & $36,7 \%$ \\
\hline Total de cartas & 502 & & 705 & \\
\hline
\end{tabular}

A caracterização do conjunto dos emissores institucionais deve antes de mais sublinhar a sua variedade já que conta com 28 emissores diferentes para Faro e 20 para Vila Viçosa. Mas é uma multiplicidade aparente (Tabela 1). Aqueles que comunicam com o município algarvio com mais regularidade e mais frequência são poucos. À cabeça vêm os emissores relacionados com o governo militar (150 e 29,8\%), onde se destaca claramente o governador e capitão general do Reino do Algarve com 138 missivas, à qual acrescem 12 emanadas do Conselho de Guerra. Sucedem-se as instâncias senhoriais com $23,1 \%$. Estas incluem as cartas enviadas pelo Conselho da Fazenda e Estado da Rainha (62), pela própria donatária (52) e uma do ouvidor e outra do juiz de fora de Faro. Em terceira posição surge a comunicação firmada pelo rei e pela chancelaria régia que agregámos como monarca (Tabela 1), com 87 ocorrências e 17,3\% do total. Todos os outros emissores se situam abaixo das 40 cartas: 32 do Conselho da Fazenda, 25 do Desembargo do Paço, 21 da Junta dos Três Estados. Entre 20 e dez emissões estão a provedoria do Reino do Algarve, a Junta da Administração do Tabaco e a própria câmara de Faro (12 cartas). Com menos de dez ocorrências, entre outros, encontram-se secretarias, corregedores, vedores, governadores militares das praças, juízes de fora de outras localidades e outras câmaras.

Quanto a Vila Viçosa, o emissor predominante é o rei, os membros da família real na qualidade de regentes e o Conselho do Rei, agrupados na categoria monarca e com um total agregado de 259 cartas, as quais perfazem $36,7 \%$ do total da correspondência registada. A curta distância situam-se os emissores senhoriais que foram signatários de 252 missivas, correspondendo a 35,7\% do total. Adoptou-se o mesmo critério seguido para Faro, pelo que se incorporaram as missivas enviadas pela Junta da Justiça da Casa de Bragança (92), pelo donatário (155) e pelos magistrados senhoriais (5). Seguem-se as 69 cartas emitidas pelo governador das Armas do Alentejo, por diversas patentes militares e por conselheiros da Guerra que se juntaram na categoria governo militar e totalizam 9,8\% do total da comunicação registada nos livros da câmara de Vila Viçosa. Embora esta questão seja desenvolvida no ponto seguinte, importa desde 
já apontar que a variedade de emissores militares encontrada em Vila Viçosa contrasta vivamente com Faro, onde o Governador do Algarve detém o quase exclusivo das emissões. A identificação dos restantes emissores registados na câmara alentejana revela que todos eles apresentam menos de 40 documentos: 32 da Junta dos Três Estados e 29 do Desembargo do Paço. Com apenas dez missivas aparece o provedor da comarca de Évora. Abaixo deste número surgem outros tribunais régios (Mesa da Consciência e Ordens e Casa da Suplicação) e outras instâncias, registando a própria câmara a emissão de apenas três cartas.

Antes de nos determos mais alongadamente sobre a comunicação dos organismos senhoriais, vale a pena sublinhar as diferenças entre as esferas de intervenção nestas terras dos dois outros principais emissores: o monarca e os governadores e patentes militares.

A diferença notória no número de cartas de origem régia verificada entre Faro e Vila Viçosa advém do facto de, no caso de Faro, a comunicação ser maioritariamente veiculada através do governador e capitão geral do Reino do Algarve. Percebe-se que em muitos casos assim foi por delegação de competências do monarca, o que teve como consequência a redução drástica do número de missivas directas da Coroa registadas nesta localidade algarvia. A historiografia tem reconhecido a diferença de esferas de actuação entre este governador e os governadores das Armas provinciais, pelo que os valores apurados não só não surpreendem como concordam com o que se conhece sobre as alargadas competências em matéria governativa que era uso deterem. Vale no entanto notar que, de acordo com F. Dores Costa, o âmbito da autoridade do governador do Algarve foi sendo discutido no Conselho de Guerra ${ }^{48}$. Apesar desta intenção limitadora, o certo é que, em Vila Viçosa, o monarca emitia de forma bastante mais significativa sobre assuntos militares e assuntos conexos com a situação de guerra do que em Faro. Mas além deste aspecto, convém também notar que o elevado número de provimentos registado em Vila Viçosa, com origem régia, está inflacionado pelas nomeações e substituições de oficiais camarários feitas pelo rei entre 1641 e 1648, ainda que saibamos que foram feitas no exercício das suas funções de donatário da Casa de Bragança.

Sem preocupação de contabilizar a importância relativa da comunicação destes dois grupos de emissores por categorias de assuntos, podem desde já destacar-se duas tendências. A primeira está associada ao assunto que se

${ }^{48}$ Fernando Dores Costa, "O Conselho de Guerra como lugar de poder: a delimitação da sua autoridade”. Análise. Social [online]. 2009, n. 191 [citado 2013-04-07], p. 379-414. Disponível em: <http://www.scielo.gpeari.mctes.pt/scielo.php?script=sci_arttext\&pid=S0003$25732009000200007 \& \operatorname{lng}=$ pt\&nrm=iso $>$. ISSN 0003-2573 
convencionou designar como participações régias. Dizem respeito a difusão legislativa que incidia sobre matérias variadas. Militares, fiscais, económicas. Mas integravam igualmente os anúncios de nascimento e morte de membros da família real, de cerimónias da monarquia ou da conclusão de pazes e tratados com potências estrangeiras. Os destinatários podiam ser genéricos ou específicos, o que significa que ora eram endereçadas com fórmulas gerais ("a todos os que este alvará virem...."), ora se dirigiam a autoridades periféricas e locais com a identificação da sua circunscrição territorial. Provedores, corregedores, ouvidores, vereações, por exemplo. Parece, assim, que a monarquia utilizava estas distintas autoridades como intermediários para a divulgação de determinações gerais, pois eram estas que as deveriam fazer ler e registar em todos os livros das câmaras da sua circunscrição. A verdade é que se verifica que as mesmas leis nem sempre foram registadas nos livros destas duas câmaras. E neste momento da investigação não se percebe exactamente qual o motivo dessa diferença. Talvez esteja directamente relacionada com as próprias características das determinações régias. Assim, legislação que incidia sobre matérias de comércio marítimo ou armadas surge em Faro e não em Vila Viçosa, enquanto no município alentejano a regulamentação sobre porte de armas assumiu maior relevo. Estas observações servem em qualquer caso para suscitar uma reflexão sobre o âmbito espacial da difusão legislativa e sobre a sua generalidade que, diga-se, este projecto de investigação também tem em agenda. Mas não neste contexto. Valerá, no entanto, adiantar ainda que nem todas as participações régias provinham do monarca. Algumas foram emitidas pelos órgãos superiores da monarquia. Junta dos Três Estados ou Desembargo do Paço. Em qualquer caso no período em análise os diferentes temas da legislação estão estreitamente relacionados com a situação de guerra. Já lá iremos.

Uma segunda tendência refere-se à maior diversidade de emissores sobre matérias associadas ao governo militar que se encontra em Vila Viçosa por comparação com Faro. Aqui o volume de cartas emitidas pelo governador do reino de Algarve era superior, o que, como já foi referido, se relaciona com a amplitude das suas competências. Nomeadamente em matéria de provimento dos postos de guerra no reino do Algarve. Segundo Dores Costa, o conselho de Guerra pretendeu equiparar nesta matéria o governador do Algarve aos governadores das Armas das províncias, o que levantou vivos protestos do governador algarvio em $1646^{49}$. Embora a questão careça de maior análise, os numerosos provimentos das mais variadas patentes militares (capitão,

\footnotetext{
${ }^{49}$ Fernando Dores Costa, "O Conselho de Guerra como lugar de poder...”.
} 
alferes, sargento, ajudante, artilheiro) sugerem que esses poderes se mantiveram com o governador do Algarve. Mas este escrevia sobre diversas outras questões militares como o processo eleitoral para os cargos, a proibição da ausência de soldados das companhias, o recrutamento e a revista às tropas; sobre as obras em muros e fortificações e a construção do forte na barra de Faro, bem como reparos em igrejas. Mas veicula também as participações régias onde sobressai a dimensão judicial, como por exemplo normas sobre o castigo ou o perdão de soldados desertores. E o perímetro espacial da sua autoridade parece de facto coincidir com o reino do Algarve. Assim sendo, o quadro comparativo pertinente relativo à actuação do governador do Algarve deveria ser os governadores territoriais das ilhas e das conquistas do Atlântico Sul e não tanto os governadores das Armas do reino.

Para além de em menor número, também o teor da documentação emitida pelo governador das Armas do Alentejo é menos variado e menos abrangente. É ultrapassado pelo monarca enquanto instância emissora sobre assuntos militares e concorre quer com outras patentes militares cujas funções exactas necessitam de mais informação, quer com o Conselho de Guerra. De facto, e apesar dos trabalhos recentes de F. Dores Costa e J. Penim de Freitas sobre este Conselho e sobre as Guerras da Restauração e de Sucessão de Espanha, ainda se conhecem mal as hierarquias do exército bem como a sua composiçãa ${ }^{50}$. Em todo o caso, valerá a pena chamar a atenção para a centralidade concedida pela monarquia à organização e à regulação das operações num dos principais teatros de guerra, assim como a maior pulverização de intervenientes. Neste último caso talvez a explicação resida antes de mais nas exigências produzidas pela centralidade defensiva do Alentejo, mas também pela montagem e o

${ }^{50}$ Fernando Dores Costa, A Guerra da Restauração 1641-1668, Lisboa, Livros Horizonte, 2004; Fernando Dores Costa, "A nobreza é uma elite militar? O caso Cantanhede-Marialva em 1658-1665”. In Nuno G. F. Monteiro, Pedro Cardim e Cunha, Mafalda Soares da (orgs.), Optima Pars. Elites Ibero-Americanas do Antigo Regime, Lisboa, Imprensa de Ciências Sociais, 2005, p. 169-190; Fernando Dores Costa, "O Conselho de Guerra como lugar de poder..."; Fernando Dores Costa, "A participação portuguesa na Guerra da Sucessão de Espanha: aspectos militares" In AA.VV., O Tratado de Methuen (1703), Lisboa, 2003, p. 71-96; Fernando Dores Costa, "Governadores das armas, mestres de campo e capitães-mores no Alentejo durante a Guerra da Restauração: inovações na administração e centros periféricos de poder" In Hermínia Vasconcelos Vilar, Mafalda Soares da Cunha e Fátima Farrica (orgs.) Centros periféricos de poder na Europa do sul ( séculos XII-XVIII). Lisboa, Edições Colibri - CIDEHUS, 2013 (no prelo). E ainda Jorge Penim Freitas, A cavalaria na Guerra da Restauração. Reconstrução e evolução de uma força militar. 1641-1668, Lisboa, Prefácio, 2005; Jorge Penim Freitas, O combatente durante a Guerra da Restauração. Vivência e comportamentos dos militares ao serviço da coroa portuguesa. 1641-1668, Lisboa, Prefácio, 2006. 
acompanhamento quotidiano de um maior volume de questões administrativas pelo Conselho de Guerra. E ainda pelas necessidades de substituição dos governadores das Armas do Alentejo, tantas vezes ausentes dos cenários de operações, por outros oficiais superiores.

\section{Fluxos de comunicação e guerra}

Recorde-se que os objectivos iniciais deste texto visavam articular o papel dos donatários na comunicação política com as suas terras com o tema da guerra. Atacando agora de forma directa estas questões centrais, importa iniciar a análise pelos fluxos de circulação. Rememorando os critérios seguidos diga-se que o conceito 'fluxo de comunicação' que aqui se utiliza implica somente a inclusão da documentação produzida com o intuito de fazer circular informação entre instituições e território. Significa, mais concretamente, que integra apenas os alvarás, provisões e cartas que foram copiados nos livros de registo das câmaras e que exclui todos os documentos registados pertencentes às tipologias certidões, licenças, sentenças, cartas de privilégio e cartas de ofício.

A comunicação registada em Vila Viçosa tem uma frequência anual média para o período considerado de 9,4. É maior do que a verificada para Faro que rondava as 6,8 missivas. Quando recortamos estes dados globais a partir dos emissores institucionais e de acordo com os intervalos temporais relativos aos períodos das guerras da Restauração e da Sucessão de Espanha estes valores pouco se alteram para Faro, crescendo até ligeiramente no período entre guerras (Tabela 2). O que não deixa de ser um pouco insólito, mesmo se Romero Magalhães nos ensinou há muito que estes conflitos tiveram repercussões marginais no Algarve ${ }^{51}$. Os dados para Vila Viçosa apresentam uma tendência de subida que se acentua ao tempo da Guerra da Sucessão ${ }^{52}$.

${ }^{51}$ Joaquim Romero Magalhães, O Algarve Económico..., p. 77-102.

${ }^{52}$ Para a necessária contextualização destas matérias na Guerra de Sucessão de Espanha, Fernando Dores Costa, "A participação portuguesa na Guerra da Sucessão de Espanha..." e Pedro Cardim, "Portugal en la guerra por la sucesión de la Monarquía española" In Francisco García González (coord.), La Guerra de Sucesión en España y la Batalla de Almansa. Europa en la encrucijada, Madrid, Sílex, 2009. 
Tabela 2 - Emissores institucionais por recortes cronológicos

\begin{tabular}{|c|c|c|c|c|c|}
\cline { 3 - 6 } \multicolumn{2}{c|}{} & \multicolumn{2}{c|}{ Faro } & \multicolumn{2}{c|}{ Vila Viçosa } \\
\hline $\begin{array}{c}\text { Recortes } \\
\text { cronológicos }\end{array}$ & $\begin{array}{c}\mathbf{N}^{\mathbf{0}} \mathbf{d e} \\
\text { anos }\end{array}$ & $\begin{array}{c}\mathbf{N}^{\mathbf{0}} \mathbf{d e} \\
\text { cartas }\end{array}$ & Média & $\begin{array}{c}\mathbf{N}^{\mathbf{0}} \text { de } \\
\text { cartas }\end{array}$ & Média \\
\hline $1641-1668$ & 28 & 181 & 6,4 & 247 & 8,8 \\
\hline $1669-1701$ & 33 & 228 & 6,9 & 294 & 8,9 \\
\hline $1702-1715$ & 14 & 93 & 6,6 & 164 & 11,7 \\
\hline Total & 75 & 502 & 6,7 & 705 & 9,4 \\
\hline
\end{tabular}

Os valores não são todavia claros relativamente ao impacto dos períodos de guerra sobre os fluxos médios de comunicação o que nos pareceu de todo em todo inesperado. Buscando esclarecer esta questão isolou-se o tema da guerra a partir do campo assuntos nele incluindo a gama alargada de efeitos que gerou - fiscalidade, obras e abastecimentos, por exemplo -, mas com desprezo pelos provimentos de cargos militares. O motivo principal desta exclusão prendeu-se com o esforço para evitar a inflação dos números destas contagens com actos decorrentes do funcionamento ordinário da governação. Em contrapartida, foram contabilizados os impactos da guerra sobre a economia e sobre a fiscalidade, já que se considerou serem consequências directas das necessidades provocadas pela situação militar. E, para evitar distorções na avaliação, decidiu-se que toda a informação sobre essas matérias seria sempre incluída, mesmo em períodos de paz.

Tabela 3 - Assuntos relacionados com a guerra (excepto provimentos) por recortes cronológicos

\begin{tabular}{|c|c|c|c|c|c|}
\cline { 3 - 6 } \multicolumn{2}{c|}{} & \multicolumn{2}{c|}{ Faro } & \multicolumn{2}{c|}{ Vila Viçosa } \\
\hline $\begin{array}{c}\text { Recortes } \\
\text { cronológicos }\end{array}$ & $\begin{array}{c}\mathbf{N}^{\mathbf{0}} \mathbf{d e} \\
\text { anos }\end{array}$ & $\begin{array}{c}\mathbf{N}^{\mathbf{0}} \mathbf{d e} \\
\text { cartas }\end{array}$ & Média & $\begin{array}{c}\mathbf{N}^{\mathbf{0}} \text { de } \\
\text { cartas }\end{array}$ & Média \\
\hline $1641-1668$ & 28 & 36 & 1,3 & 86 & 3,1 \\
\hline $1669-1701$ & 33 & 34 & 1,0 & 27 & 0,8 \\
\hline $1702-1715$ & 14 & 34 & 2,4 & 55 & 3,9 \\
\hline Total & 75 & 104 & & 168 & \\
\hline
\end{tabular}

Os resultados assim obtidos revelaram-se bastante mais conformes às expectativas iniciais, demonstrando que o tema da guerra assumiu um indiscutível relevo na comunicação política com estas terras. Ou seja, 20,3\% (104) das cartas registadas em Faro e uns ainda mais expressivos 23,8\% (168) em 
Vila Viçosa. Mas se se atender à sua distribuição cronológica a questão fica ainda mais evidente (Tabela 3 ).

Com efeito, as flutuações médias anuais revelam que o período entre guerras apresenta valores mais baixos. Para Vila Viçosa as cartas referem essencialmente questões associadas à fiscalidade - meias anatas, real da carne e vinho, papel selado, contribuição do usual, a finta dos 4,5\% - embora muitas vezes expliquem que aplicação dessas verbas visava obras de fortificação. Algumas outras regulam o uso de armas de fogo e outras ainda as condições de recrutamento militar. Já em Faro a questão fiscal parece pesar menos neste cômputo, embora também apareça associada à manutenção das estruturas defensivas, adquirindo maior expressão as matérias relativas ao recrutamento e à gestão, ao treino e aprovisionamento das tropas por lá estacionadas.

Em tempo de guerra a comunicação é mais numerosa. Aborda o mesmo tipo de assuntos em ambas as localidades e revela a mesma interrelação entre a guerra e a fiscalidade, detectando-se no entanto uma maior preocupação com as necessidades de recrutamento e as deserções de soldados em Faro, com a criação de cavalos, as munições e o abastecimento em Vila Viçosa ${ }^{53}$.

Assim se como apontado na Tabela 2 a pressão militar não é suficiente para explicar as variações dos fluxos globais de comunicação, compreende-se igualmente que essas matérias pouco constavam das competências senhoriais. A Tabela 4 demonstra-o com bastante evidência e a análise mais fina dos conteúdos da correspondência confirma-o plenamente.

Tabela 4 - Emissores senhoriais por recortes cronológicos

\begin{tabular}{|c|c|c|c|c|c|}
\cline { 3 - 6 } \multicolumn{2}{c|}{} & \multicolumn{2}{c|}{ Faro } & \multicolumn{2}{c|}{ Vila Viçosa } \\
\hline $\begin{array}{c}\text { Recortes } \\
\text { cronológicos }\end{array}$ & $\begin{array}{c}\mathbf{N}^{\mathbf{0}} \text { de } \\
\text { anos }\end{array}$ & $\begin{array}{c}\mathbf{N}^{\mathbf{0}} \mathbf{d e} \\
\text { cartas }\end{array}$ & Média & $\begin{array}{c}\mathbf{N}^{\mathbf{0}} \text { de } \\
\text { cartas }\end{array}$ & Média \\
\hline $1641-1668$ & 28 & 29 & 1,0 & 49 & 1,8 \\
\hline $1669-1701$ & 33 & 51 & 1,5 & 138 & 4,2 \\
\hline $1702-1715$ & 14 & 36 & 2,5 & 65 & 4,6 \\
\hline Total & 75 & 116 & 1,5 & 252 & 3,4 \\
\hline
\end{tabular}

Com efeito para Faro, as questões militares e fiscais estão quase omissas na comunicação senhorial e as que existem estão ligadas a nomeações e à

${ }^{53}$ Para o contexto da guerra em cenários alentejanos com claras interrelações com os conteúdos da comunicação registada em Vila Viçosa, Fernando Dores Costa, “A participação portuguesa na Guerra da Sucessão de Espanha...”. 
clarificação de competências de recrutamento das guarnições com o governador do Algarve. O mesmo nível de mutismo ocorre em Vila Viçosa e a análise da documentação revela com clareza que a intensificação da correspondência dos donatários durante o período da Guerra de Sucessão nada tem a ver com o conflito. Fica assim estabelecido que, salvaguardando o provimento de cargos militares e alguma conflitualidade dela decorrente, o tema da guerra pouco afecta a relação entre os donatários e as suas câmaras.

Daqui se conclui que as matérias relacionadas com o esforço militar estão cometidas a outras instâncias de governo que não as senhoriais. No que respeita a Vila Viçosa são claramente geridas pelo centro político, pontuando as missivas firmadas pelo rei, pela Junta dos Três Estados ou por conselheiros da Guerra. Pode-se então concluir que a regionalização da logística da guerra tem pouco relevo no Alentejo, onde o governador das Armas desempenha um papel discreto, diferenciando-se claramente de Faro onde o Governador e Capitão General do Reino do Algarve assumiu uma intervenção decisiva.

\section{Os receptores e os temas dominantes da comunicação senhorial.}

De acordo com a Tabela 4 que apresenta a comunicação dos emissores senhoriais distribuída por recortes cronológicos verifica-se uma subida continuada da correspondência entre estes e os seus municípios que estará associado à (re)criação destas duas casas após a Restauração e à subsequente institucionalização das mesmas.

Assim, o facto de entre 1641 e Dezembro de 1648 ser o rei a assinar a documentação senhorial para Vila Viçosa, sem fazer qualquer menção à sua qualidade de donatário, introduz uma contracção artificial nos números das emissões senhoriais que terá impacto nos valores médios apontados para o primeiro recorte cronológico. Foi, no entanto, uma situação que se resolveu a partir de Janeiro de 1649 , pois o monarca passou a assinar a documentação invocando expressamente o seu papel de administrador da Casa. Será essa a mais provável justificação para os números médios indicados para os dois períodos subsequentes serem bastante superiores. Já a semelhança de valores em contextos político-militares tão diferenciados exige uma explicação cruzada com os temas dessa mesma correspondência. Já lá iremos.

Algo de semelhante terá ocorrido em Faro. No caso, a inclusão de Faro na Casa da Rainha em Fevereiro de 1642 e o aparecimento apenas em 1669 do ouvidor senhorial a substituir o corregedor podem bem justificar a exiguidade da comunicação média anual para o período inicial, enquanto a progressiva institucionalização dos procedimentos administrativos explicará o posterior 
crescimento dos valores médios de correspondência senhorial. São valores em todo o caso bastante mais baixos que os verificados para Vila Viçosa. Como foi dito anteriormente, parte desta diferença prende-se com a inclusão para Vila Viçosa das 108 cartas originais anexas aos livros de vereação.

Tabela 5 - Emissores senhoriais - assuntos (1641-1715)

\begin{tabular}{|c|r|r|r|r|}
\hline Assuntos & \multicolumn{2}{|c|}{ Faro } & \multicolumn{2}{c|}{ Vila Viçosa } \\
\hline Justiça e Polícia & 34 & $29,3 \%$ & 55 & $21,8 \%$ \\
\hline Pagamentos & 17 & $14,7 \%$ & 2 & $0,8 \%$ \\
\hline Provimentos & 32 & $27,6 \%$ & 158 & $62,7 \%$ \\
\hline Outros & 33 & $28,4 \%$ & 37 & $14,7 \%$ \\
\hline Total & 116 & $22,7 \%$ & 252 & $35,5 \%$ \\
\hline
\end{tabular}

Nas cartas enviadas pelas instituições senhoriais em Faro destacam-se como temas dominantes os do âmbito de justiça e polícia, pagamentos e provimentos. Os pagamentos surgem mais destacados em Faro, enquanto as questões de justiça e polícia e, sobretudo, os provimentos se evidenciam em Vila Viçosa. Para melhor explicar estas ocorrências convém perguntar a quem se dirigiam estas cartas, ou seja quem eram os interlocutores do governo senhorial central nestas duas terras? Faremos a análise a partir dos dados desagregados por documentos emitidos pelo donatário e pelos tribunais centrais das casas já que parece haver uma divisão de matérias sobre os quais cada um intervinha.

Os documentos emitidos pelo titular da Casa de Bragança destinam-se maioritariamente e de forma directa à câmara de Vila Viçosa. Com efeito, em 155 emissões, 130 têm a câmara como destinatário. Versam a nomeação, a escusa ou a substituição de oficiais periféricos, camarários ou outros de âmbito local, assim contribuindo para explicar o empolamento da categoria provimentos. De resto e reforçando os alertas que temos vindo a fazer sobre as cautelas a introduzir na comparação destes dois municípios, recorde-se que estes números incluem as já referidas 108 cartas anexas aos livros de vereação e que quase todas visam informar a vereação sobre provimentos de oficiais camarários.

Dos restantes documentos emitidos pelo donatário brigantino, 21 são alvarás que apresentam o conhecido formulário de destinatário genérico: "aos que este alvará virem"; três dirigem-se ao ouvidor da comarca e apenas um ao juiz de fora. Em qualquer dos casos vale sublinhar que destes 21 alvarás apenas sete tratam de matérias diferentes do provimento de ofícios. O endereçamento genérico destes 14 alvarás de provimento explicar-se-á pelo facto de terem 
sido enviados aos providos (ao ouvidor, ao juiz de fora, ao coudel, ao escrivão, ao tabelião, ao avaliador, etc.) e depois copiados nos livros de registo da câmara. No que toca às cartas destinadas ao ouvidor e ao juiz de fora, estas têm como objectivo conceder-lhes licença para se ausentarem do lugar de exercício durante determinado período. Existe uma excepção dirigida ao ouvidor de Vila Viçosa, em 1712, que trata as eleições dos vereadores nas câmaras das terras da Casa de Bragança ${ }^{54}$.

Já os receptores das cartas da Junta da Justiça da Casa de Bragança são maioritariamente os oficiais periféricos da própria Casa. Em 92 emissões 47 tiveram como destinatários o ouvidor senhorial (28) ou o juiz de fora (19), o que coloca estes oficiais num papel de destaque na intermediação da comunicação entre o poder central da Casa e as localidades. Os temas abordados são muito diversificados dominando os assuntos directamente ligados a questões de justiça e polícia quer nas cartas recebidas pelo ouvidor da comarca (16) quer pelo juiz e fora (13). Como era expectável, de resto, dadas as funções destes magistrados. Mas, ao contrário do que se observou para as cartas emitidas pelo donatário, a Junta enviou apenas 42 cartas directamente para a câmara de Vila Viçosa. Sobressaem os provimentos de ofícios (15) e as questões de justiça e polícia (10). As restantes referem-se a temas variados como fiscalidade, economia, pagamentos, aspectos militares, privilégios ou representação e cerimónias.

Em Faro também a Rainha emitiu correspondência sobretudo para a câmara. Em 52 cartas, 21 têm este destinatário. Versam conteúdos muito diversificados - justiça e polícia, fiscalidade, economia, questões militares, provimentos de ofícios - não havendo nenhuma dominância clara. Outras 16 cartas destinam-se a indivíduos específicos que nomeia em diversos cargos (ouvidores, juízes ou postos militares). Entre as restantes não há nenhuma para a ouvidoria de Faro; encontra-se apenas uma para o juiz de fora; três para o governador do Reino do Algarve, sobre a eleição de postos militares; duas para o corregedor de Tavira, para fazer correição nas suas terras antes de 1669; e oito para instituições religiosas: quatro para o convento de Santo António de Faro e quatro para o Colégio da Companhia de Jesus da mesma cidade. Todas estas se referem à concessão de esmolas a estes institutos, excepto uma que autoriza que o reitor do colégio da Companhia possa mandar prender os estudantes pelas justiças seculares ${ }^{55}$. Como se constata, embora os receptores sejam variados, $\mathrm{o}$ assunto mais frequente é o provimento de ofícios.

\footnotetext{
${ }^{54}$ AHMVV, Câmara de Vila Viçosa, RG 722, fl. 406v.

${ }^{55}$ ADF, Câmara de Faro, Sr. A/1, Lv. 01, fl. 198v.
} 
Igualando o que se verifica para a Casa de Bragança, entre os destinatários do Conselho da Fazenda e Estado da Rainha sobressaem os oficiais periféricos da Casa. Num total de 62 cartas emitidas, 30 são dirigidas ao ouvidor (16) e ao juiz de fora de Faro (14). A maioria das cartas para o juiz de fora aborda questões de justiça e polícia (8), mas o mesmo não se passa com as dirigidas ao ouvidor onde as temáticas são diversas (provimentos, fiscalidade, economia, questões militares, etc.). Para a câmara seguiram 20 cartas abrangendo um grande leque de temas - fiscalidade, economia, pagamentos, provimentos, justiça e polícia - sem que nenhum apresente um destaque visível. Das restantes 12 cartas emitidas pelo Conselho apenas merece destaque o corregedor da comarca de Tavira que recebeu quatro missivas. Duas relacionam-se com as funções exercidas pelos corregedores enquanto ouvidores da Casa, antes de $1669^{56}$. As outras duas são posteriores a essa data e têm o mesmo fim: ordenar que o corregedor tire residência ao ouvidor e provedor da $\mathrm{Casa}^{57}$. Tal como na Casa de Bragança, também na Casa da Rainha os oficiais régios eram um recurso para a fiscalização da actuação dos ministros senhoriais. Facto é, seja nas cartas para os juízes de fora, seja nas enviadas para os corregedores, que os temas preferenciais andam em torno das questões de justiça e polícia. Convém, no entanto, ressalvar que, na maior parte dos casos, não se trata da resolução de questões judiciais, mas da tramitação ordinária de assuntos de administração e governo: ordenar a realização de eleições, determinar competências de magistrados, impor proibições, arbitrar conflitos, garantir a salvaguarda de privilégios, determinar o lugar de cada um nas cerimónias realizadas. Mais do que punir o que se promove é a paz e a concórdia entre os vassalos bem como a defesa dos direitos e privilégios da Casa.

Quanto aos pagamentos, estes distribuem-se por aposentadorias, propinas, ordenados, levas de presos, obras e esmolas. Na categoria Outros englobam-se todas as cartas referentes a temas como: economia, fiscalidade, militar, privilégios, representação e cerimónias e obras.

Importa por fim sublinhar uma divisão de áreas de intervenção entre os titulares destas casas e os respectivos tribunais superiores que pode ser verificada pelo cruzamento dos temas da comunicação com os destinatários das mesmas que acima se descreveu. Assim, os donatários escreviam sobretudo para exercer a sua prerrogativa de nomeação dos oficiais periféricos e locais, enquanto a Junta e o Conselho exerciam as suas funções de tribunal arbitral sempre

\footnotetext{
${ }^{56}$ ADF, Câmara de Faro, Sr. A/1, Lv. 01, fl. 137 e Sr. A/1, Lv. 01, fl. 137v.
}

${ }^{57}$ ADF, Câmara de Faro, Sr. A/1, Lv. 01, fl. 188 e Sr. A/1, Lv. 01, fl. 208v. 
que necessário, correspondendo-se, sobretudo com as instâncias intermédias - o ouvidor e o juiz de fora.

Como a literatura sobre a matéria já tinha constatado ${ }^{58}$, em ambos os municípios sobrelevam os aspectos relacionados com o exercício ordinário da jurisdição senhorial ou seja provimento de ofícios e o que se classificou como 'Justiça e Polícia' (ordens para a realização de eleições para cargos camarários, regulamentação da acção dos ouvidores em correição, mandados para tomada de residências a ministros da Casa). Correspondem afinal aos objectivos mais tradicionais da governação no Antigo Regime.

\section{Conclusão}

Como se disse antes e se percebe pela natureza ainda bastante descritiva deste trabalho, esta análise constitui um primeiro ensaio de tratamentos serial de dados sobre a comunicação política e sobre a comunicação senhorial feita a partir de uma documentação que tem sido pouco utilizada para estes efeitos. O que implica que as conclusões tenham um carácter relativamente provisório, sobretudo no que respeita ao enquadramento em contextos mais amplos. Nomeadamente na comparação de longa duração com outros municípios e com outros territórios do Império. Mas, em sentido inverso, seria, por exemplo, recomendável uma micro análise dos conflitos entre as autoridades e os poderes presentes nos diferentes espaços locais.

Feita esta advertência acreditamos que se podem adiantar algumas ideias gerais sobre os sentidos da comunicação política deste tipo de senhorios com as suas terras. Uma primeira serve para sublinhar a persistência da autoridade senhorial sobre os territórios, pois a comunicação registada ocupa entre um quarto e um terço do total de registos efectuados. Mas os temas dessa comunicação dizem sobretudo respeito ao governo ordinário dos quotidianos das localidades. Gestão corrente, poder-se-ia talvez dizer, onde pontuam os provimentos de ofícios e na qual se deve sublinhar o importante papel de mediadores que é conferido aos magistrados senhoriais, ou seja aos ouvidores e aos juízes de fora.

${ }^{58}$ António M. Hespanha, Justiça e Administração entre o Antigo Regime e a Revolução, sep. Hispania. Entre Derechos Proprios y Derechos Nacionales, eds. Bartolomé Clavero, Paolo Grossi e Francisco Tomás y Valiente, t. I, 1990 e já aplicado a estes mesmos casos senhoriais por Maria Paula Marçal Lourenço, Casa, Corte e Património..., vol. 2, p. 755 e Mafalda Soares da Cunha, A Casa de Bragança (1560-1640)..., p. 215 e ss. 
O outro agregado de questões que surge como mais significativo na comunicação senhorial prende-se com o esclarecimento dos contornos ou a salvaguarda dos direitos jurisdicionais das duas casas. Neste particular - que deveria ser melhor esclarecido com a análise sistemática dos conflitos jurisdicionais -, parece que a actuação das instâncias senhoriais se dirigia principalmente à defesa dos direitos detidos ancestralmente pelas casas. Ou seja, ao contrário do que teria ocorrido em séculos anteriores - certamente no século XVI - os donatários não procuraram ampliar a sua esfera de intervenção sobre as suas terras através da incorporação (ou da actualização) de novos direitos político governativos. Visavam a conservação dos que já detinham, o que passava inevitavelmente pela defesa face a outras dimensões de poder que se apresentavam mais dinâmicas na ampliação do seu âmbito de competências.

Essa a razão pela qual as instâncias de governo militar e o próprio monarca surgem com o maior volume de comunicação. Os assuntos associados ao novo quadro político saem fora da alçada destes donatários como se verifica com as novidades em matéria fiscal ou com as questões relacionadas com o recrutamento e o comando militar. Contrariamente ao que ocorrera em outros tempos, estes donatários não procuraram situações de excepção para as suas terras, nem sequer o papel de mediadores com o centro político. $\mathrm{O}$ que justifica que a divulgação legislativa não corra por seu intermédio, quando se viu que tal ocorria com o governador do Algarve que desempenhava uma função de mediador com contornos regionais entre o centro e o reino do Algarve. Socorrendo-nos de novo dos dados do projecto A comunicação política na monarquia pluricontinental portuguesa pode desde já adiantar-se que esta conclusão se aplica as governadores do Estado do Maranhão e das demais capitanias do Brasil. Também lá o governador era o principal intermediário da comunicação, desta feita com o Conselho Ultramarino. A partir da observação feita em Vila Viçosa não se visualiza a emergência de qualquer poder de âmbito regional por parte do governador das Armas do Alentejo. O que se verifica é uma disputa e uma partilha de espaço de intervenção sobre as matérias candentes da governação da monarquia (fiscalidade, guerra, economia) por parte de diferentes organismos centrais ou por acção directa do próprio rei.

A constatação deste relativo esvaziamento do poder político senhorial confirma assim a ideia de que os donatários das casas de Bragança e da Rainha - rei e rainha - tinham a possibilidade de reforçar o seu espaço de intervenção e de afirmação política no reino através de novos dispositivos políticos e que, portanto, não necessitavam da sua posição de donatários para o fazer.

Mas, para finalizar, importa sublinhar que o determinante papel que os titulares dos senhorios mantiveram nos seus territórios - e sabemos como eram 
geograficamente extensos - sobre a escolha e a confirmação de nomes para exercer o poder à escala local (oficialato camarário e, sobretudo, vereações) não recomenda que se descarte a dimensão do poder senhorial do jogo político.

\section{Fontes e Bibliografia}

\section{Fontes Manuscritas}

Arquivo Histórico Municipal de Vila Viçosa

Câmara de Vila Viçosa, RG 703 e 722

Câmara de Vila Viçosa, RG 738 a 791

Arquivo Distrital de Faro

Câmara de Faro, Sr. A/1, Livro 01, 02 e 03

\section{Fontes Impressas}

FERRÃO, F. A. F. Silva, Tractado sobre Direitos e Encargos da Sereníssima Casa de Bragança, Lisboa, Imprensa de J.J. Andrade e Silva, 1852.

Ordenações Manuelinas, nota de apresent. Mário Júlio de Almeida Costa, Lisboa, Fundação Calouste Gulbenkian, 1984, Livro 1.

Ordenações Filipinas, nota de apresent. Mário Júlio de Almeida Costa, Lisboa, Fundação Calouste Gulbenkian, 1985, Livro 1.

Regimento da Serenissima Casa de Bragança, Lisboa, Officina de Miguel Manescal, 1690.

SANTARÉM, $2^{\circ}$ Visconde de, Memórias e Alguns Documentos para a História e Teoria das Côrtes Geraes que em Portugal se Celebraram pelos Três Estados do Reino. Parte II. Documentos, Lisboa, Impressão Régia, 1828. SILVA, José Justino de Andrade e (comp. e anot.), Collecção Chronologica da Legislação Portugueza - 1640-1647, Lisboa, Imprensa de J. J. A. Silva, 1854. SOUSA, José Roberto Monteiro de Campos Coelho e, Systema, ou Collecção dos Regimentos Reaes, Lisboa, Oficina de Francisco Borges de Sousa, Tomo V, 1789.

\section{Bibliografia}

CARDIM, Pedro, "Portugal en la guerra por la sucesión de la Monarquía española” In Francisco García González (coord.), La Guerra de Sucesión 
en España y la Batalla de Almansa. Europa en la encrucijada, Madrid, Sílex, 2009.

COSTA, Fernando Dores, "A participação portuguesa na Guerra da Sucessão de Espanha: aspectos militares" In AA.VV., O Tratado de Methuen (1703), Lisboa, 2003, p. 71-96.

COSTA, Fernando Dores, A Guerra da Restauração 1641-1668, Lisboa, Livros Horizonte, 2004;

COSTA, Fernando Dores, "A nobreza é uma elite militar? O caso Cantanhede-Marialva em 1658-1665”. In Nuno G. F. Monteiro, Pedro Cardim e Cunha, Mafalda Soares da (orgs.), Optima Pars. Elites Ibero-Americanas do Antigo Regime, Lisboa, Imprensa de Ciências Sociais, 2005, p. 169-190.

COSTA, Fernando Dores, "O Conselho de Guerra como lugar de poder: a delimitação da sua autoridade”. Análise. Social [online]. 2009, n. 191 [citado 2013-04-07], p. 379-414.Disponível em: <http://www.scielo.gpeari.mctes.pt/ scielo.php?script=sci_arttext\&pid=S0003-25732009000200007\&lng=pt \&nrm $=$ iso $>$.

COSTA, Fernando Dores, "Governadores das armas, mestres de campo e capitães-mores no Alentejo durante a Guerra da Restauração: inovações na administração e centros periféricos de poder" In Hermínia Vasconcelos Vilar, Mafalda Soares da Cunha e Fátima Farrica (orgs.) Centros periféricos de poder na Europa do sul (séculos XII-XVIII). Lisboa, Edições Colibri CIDEHUS, 2013 (no prelo).

CUNHA, Mafalda Soares da, "A Casa de Bragança (séculos XIV-XVIII): Permanência, plasticidade e participação política", in D. João VI: um rei aclamado na América - Anais do Seminário Internacional, Rio de Janeiro, Museu Histórico Nacional, 2000.

CUNHA, Mafalda Soares da, A Casa de Bragança (1560-1640): práticas senhoriais e redes clientelares, Lisboa, Editorial Estampa, 2000.

FARRICA, Fátima, Poder sobre as periferias: a Casa de Bragança e o governo das terras no Alentejo (1640-1668), Lisboa, Colibri. CIDEHUS-UÉ, 2011. FONSECA, Jorge, “A população do arcebispado de Évora em 1592”, Callípole, $\mathrm{n}^{\mathrm{os}} 10-11,2002-2003$, p. 33-47.

FREITAS, Jorge Penim, A cavalaria na Guerra da Restauração. Reconstrução e evolução de uma força militar. 1641-1668, Lisboa, Prefácio, 2005.

FREITAS, Jorge Penim, O combatente durante a Guerra da Restauração. Vivência e comportamentos dos militares ao serviço da coroa portuguesa. 1641-1668, Lisboa, Prefácio, 2006.

HESPANHA, António Manuel, As Vésperas do Leviathan: Instituições e Poder Político: Portugal-séc. XVII, Lisboa, 1986. 
HESPANHA, António Manuel, Justiça e Administração entre o Antigo Regime e a Revolução, sep. Hispania. Entre Derechos Proprios y Derechos Nacionales, eds. Bartolomé Clavero, Paolo Grossi e Francisco Tomás y Valiente, t. I, 1990.

LOURENÇO, Maria Paula Marçal, Casa Corte e Património das Rainhas de Portugal (1640-1754): Poderes, Instituições e Relações Sociais, Lisboa, Universidade de Lisboa, 1999, (Tese de Doutoramento policopiada), Vol. 1 e 2.

MAGALHÃES, Joaquim Romero, O Algarve Económico. 1600-1773, Lisboa, Editorial Estampa, 1988.

MONTEIRO, Nuno Gonçalo, O Crepúsculo dos Grandes: A casa e o património da aristocracia em Portugal (1750-1832), $2^{\mathrm{a}}$ ed. revista, Lisboa, Imprensa Nacional-Casa da Moeda, 2003.

RODRIGUES, Ana Maria S. A., "Poderes Concorrentes e seus Agentes na Torres Vedras Quatrocentista," Amar, Sentir e Viver a História. Estudos de Homenagem a Joaquim Veríssimo Serrão, Lisboa, 1995, p. 49-73.

SILVA, Manuela Santos, A Região de Óbidos na Época Medieval: Estudos, Caldas das Rainha, 1994.

SUBTIL, José, "O Estado e a Casa da Rainha: entre a véspera do terramoto e o Pombalismo", Politeia: História e Sociedade, Vol. 8, n 1, 2008, p. 129-163. 